\title{
Geographic Information System for Booking Beauty Salon and Barber Shop with an Android-Based E-CRM Approach
}

\author{
I Kadek Dharma Krisna Putra \\ Department of Information \\ Technology \\ Faculty of Engineering \\ Udayana University \\ Badung, Bali, Indonesia
}

\author{
I Nyoman Piarsa \\ Department of Information \\ Technology \\ Faculty of Engineering \\ Udayana University \\ Badung, Bali, Indonesia
}

\author{
I Made Sukarsa \\ Department of Information \\ Technology \\ Faculty of Engineering \\ Udayana University \\ Badung, Bali, Indonesia
}

\begin{abstract}
Beauty salons and barber shop are a necessity for almost everyone. Nowadays, the business processes of them mostly still use conventional methods. The method gives obstacles to customers who have a lot of activities, for example, they have to come directly to the beauty salon or barber shop to take the queue. In addition, it is hard to promote, communicate and assess without ECRM media. The location is also difficult to find because there is no guide mark on Google Maps. The Geographic Information System for Booking Beauty Salon and Barber Shop provides solutions for making scheduled bookings and transactions by using the eCRM approach as in the application of promotional features to attract customers. There are some features offered in the application, such as chat features for communication, rating and review features to assess the services obtained, and route feature as a solution to show the location of selected vendors. The implementation process requires an Android smartphone and a computer device with software including Android Studio, SQLYog, XAMPP, and Visual Studio Code. The results of the implementation is the system can be successfully applied based on experiments and testing directly.
\end{abstract}

Keywords: Geographic Information Systems, Booking, Promotion, E-CRM, Android

\section{INTRODUCTION}

Beauty salon is a place for hair care and makeup that generally serves female customers, while barbershop is a place for hair, moustache or beard care that serves male customers. The numbers of service providers make it difficult for customers to make choices in finding the suitable one. This is also caused by not establishing a good relationship between service providers and service users, for example, incompatibility of promotional services offered, service quality, and price offered. This need is trying to be accommodated by providing information systems to facilitate interactions between users and service providers that include bookings, promotions, transactions, chatting features that can be accessed using an Android device. This system is implemented by an E-CRM approach that prioritizes customer satisfaction and loyalty. There are several features offered by this system, for example the implementation of a payment system with an electronic wallet model that can be refilled as a means of payment, the availability of chat features to communicate directly with service providers, there are rating and review features to get an overview of service quality provided or as an assessment of services provided, and customers can also use promotions provided by service providers.

There are several studies used as references in the recent study to produce solutions related to online ordering, GIS, and CRM. A research conducted by I Putu Warma Putra produced an application that facilitates customers in ordering a taxi and assisting the driver in picking up a customer. Some of the steps conducted are system analysis, system design, and system implementation. [1]

Yuwono, Aribowo and Setyawan conducted a research that developed a geographic information system for tourism in the Magelang area based on Android. The system can be connected directly with Google Maps. The result is the system can provide information about tourism location in the Magelang area easily because it can be operated wherever the user's location is. Therefore, this result is in accordance with the purpose of the developed application. Overall, the application successfully provides tourism information and the best tourism location from the user's position. [2]

Yunefri, Devega and Kristanto developed a web-based GIS application with the aim of providing information about culinary in Pekanbaru based on the user's location. The development of the application is carried out by using the PHP programming language and the Harversine method to determine the closest distance of a restaurant. The results of the obtained data were tested by using a black box to show that a test by using this application is similar to the manual method. [3]

A research conducted by Neene and Kabemba is the expansion of a property mapping application with a geographic information system that can be used by local authorities in developing countries. The result of this study showed this application did not require the acquisition of attribute, spatial, and real-time image data from properties. The study was strengthened by conducting a survey on the Kafue local authority to meet the requirements needed by the system. After designing and modelling, the developed system was tested on the field with the results of 10 properties were successfully mapped. [4]

A research conducted by Kusnawi discussed ordering problems that cause inconvenience to customers, such as running out of seats and also uncertainty. This problem is trying to be solved by providing a table and food ordering information system and placing it on the main server of a desktop-based restaurant. The results can be developed into web and desktop applications. The desktop application is a medium to verify online orders made by customers via the web, therefore, different platforms orders can still be entered and verified. This system supports the use of balances that can be topped up as a means of payment. [5]

Aulia Aulia, Zakir, Dafitri, Siregar, \& Hasdiana conducted a research that related to the situation in the restaurant. This 
study designed a system that can speed up ordering and food processing in restaurants. The results of this study also allow ordering data to be sent over a wireless network that connects smartphones to computers in the kitchen. As the result, the order can be directly read by the chef because it is shown on the LCD screen. [6]

A research conducted by Rosadi and Andriawan developed an Android-based system that can facilitate in finding boarding houses from certain areas and also promote boarding houses found in the city of Bandung. The methods used in this research are descriptive analysis and development, data collection methods, and object-oriented system development methods. The results of this study indicate that an application for a boarding house can facilitate users in obtaining information, therefore the users can find boarding houses easily and according to their criteria. [7]

A research conducted by Mila Afrina and Ali Ibrahim used ECRM concept. It resulted in a strategy to obtain, consolidate and analyze data to be used to interact with customers (students, students, teachers, lecturers, and the community). Thus, a comprehensive view of the customer and a better relationship with the customer are created. [8]

A research conducted by Le Tan discusses the progress of information technology. Thereby, it drives changes in consumer behaviour in shopping, especially in e-commerce. The results obtained are indicators of the success of e-CRM implementation in e-commerce companies. This research uses a descriptive method with the Library Research approach by looking at several previous journals and using three indicators: customer complaints, customer loyalty and management control of e-CRM implementation. The result is that these indicators can be used as a benchmark in determining the level of success in implementing e-CRM in an e-commerce. [9]

A research conducted by Tamara Luarasi, Andi Domi, Tomi Thomo, Agim Kasaj, and Ergon Baboci explained that the latest technology has supported the latest business scenarios and the application of existing ones. Its application has been tested on the livestock market, which is in dire need of the presence of technology especially in difficult rural zones. This study represents the method used in making digital brokers. [10]

Neny Rosmawarni developed a system that provides recommendations for application development. This study uses a collaborative filtering method, where the data is taken based on user feedback such as reviews and ratings. This application is an Android-based and was tested in the field of beauty like a beauty salon. With some recommendations from this application, the users can consider a beauty salon that matches their needs, budget and the suitability of the type of care provided based on the needs of the user. [11]

An information system with the implementation of web-based customer relationship management (CRM) is the final result of a research conducted by Tukino. It can be used to manage customer complaints with PT Indoritel Makmur International Tbk (Indomaret) Batam as the case study. The method used is Extreme Programming which is most widely used approach for developing this software. The results of this study are CRM information systems with a web platform [12]

Irvan Prastya, Sarip Hidayatuloh and Nidaul Hasanati conducted a research by designing a website-based E-CRM information system at PT Persada Duta Beliton. It can be used for maintaining company relationships with customers. The results of this study are the system has a tour package booking feature, a chat feature for customer communication and a feature for giving tours package reviews based on customer experience. In addition, there is a promotional media for the customer, such as congratulating a celebration by giving gifts in the form of discounts to them. The model in developing the system is the Rapid Application System (RAD). The system design is conducted with UML. [13]

Anharudin, Donny Fernando and Novi Khristina Putri developed an E-Booking Information System that can be used to facilitate customers to order karaoke rooms at Happy Puppy in Cilegon City. The application is developed and designed by using UML modelling. In addition, it is created with the PHP programming language and uses MySQL to store the database. The existence of an E-Booking Information System is expected to help customers in ordering karaoke rooms at Happy Puppy in Cilegon City, Banten. [14] A research conducted by Devi Mawarni and Rinabi Tanamal developed an information system for a medium scale beauty salon by using Visual Basic 2010 programming with SDLC waterfall. The study was conducted by interviews to obtain and conduct data analysis. The implementation resulted in a program that could solve the problems found in medium-scale beauty salons. [15]

Research conducted by Luh Gede Sri Handayani, I Nyoman Piarsa, Kadek Suar Wibawa produced a geographic information system for web-based village road mapping. This system using Google Maps, with the polyline feature making it possible to describe the road network and geometry library that can calculate road lengths. Data collection on this system is done by two ways, digitizing and input coordinates, and processing data on master data. The results of this mapping provide information of road names, types of road surfaces, road lengths and road conditions. [16]

Research conducted by I Made Widnyana, I Nyoman Piarsa, A. A. K. Agung Cahyawan W developed a geographic information system to map the location of workshops in Denpasar. This system can be accessed using an Android smartphone with Google Maps API support that allows user to find out information about the workshop. The results of this study are the application can allow users to get route information with the direction feature. User can see detailed information about services and spare parts provided by the workshop. For workshop owners can update service information and create promos. [17]

Research by I Wayan Wahyu Gautama, I Ketut Gede Darma Putra, I Made Sukarsa produced a geographic information system for mapping coastal tourism objects in southern Bali. This application is designed using the Google Maps API which can be run on android devices. The test results obtained a percentage of $80 \%$ with a very good value in terms of the presentation of content and beach information, this application can also display the route to the beach. [18]

Based on the background and references above, this research focuses on developing a system that facilitates interaction between the service providers of beauty salon and barber shop with customers. There is a difference of the current study with the previous one. In the previous study, there has been no solution that facilitates salon and barber users. It is because the previous study only focused on one vendor, unscheduled bookings, and the unavailability of e-CRM features such as promotions, chat, ratings and reviews. There are some topics that still be used as supporting references in building a beauty salon and barbershop information system such as E-CRM, booking or booking, using Google maps in GIS and so on. This research is also expected to develop a friendly system for various vendors. 


\section{LITERATURE REVIEW}

The literature Review discusses about supporting theories in conducting the study, such as Android, Android Studio, Geographic Information System (GIS), E-CRM and Database.

\subsection{Android}

Android is a software that is commonly used on smartphone devices which includes operating systems, middleware and key applications. Android-based application development can be performed by using the Java and Kotlin programming languages. Android OS has core applications including SMS programs, contacts, browsers, maps, calendars, e-mails and others. Android is an open source platform, therefore developers are free to participate in developing applications for Android devices that are great in capabilities and innovative. The android developers are also given the freedom to access hardware information, access location information, run background services applications, set alarms, make notifications to the status bar, and many more.

\subsection{Android Studio}

Android Studio is an Integrated Development Environment (IDE) that is used to develop applications based on the Android operating system and created with the IDB's JetBrains IntelliJ software. IDE makes it easier for android application developers. In addition, it replaces Eclipse Android Development Tools (ADT) which were previously the main IDE for Android application development. Android studio was announced for the first time at the Google I / O conference on May 16, 2013. On May 2013, it was still a preview of version 0.1 until it was released in June 2014 where it had entered the beta stage with version 0.8 . The stable version was finally released in December 2014, with version number 1.0

\subsection{Geographic Information System (GIS)}

Geographical Information System (GIS) is an information system that can store, process, analyze, and provide information based on user's geographic references. It is a system for utilizing and producing spatial data process and analysis as well as non-spatial data in obtaining various information related to spatial aspects, both scientific, commercial, management and policy oriented.

\subsection{E-CRM}

E-CRM is a business strategy that uses information technology that gives companies a broad, reliable and integrated customer view. In other words, all customer processes and interactions can be used to be processed and analyzed with the aim of finding strategies to maintain and expand profitable relationships simultaneously. Furthermore, E-CRM is a powerful and flexible platform intended to facilitate customers in interacting with companies. It is also a CRM that is applied electronically by using media such as web browsers, the internet and electronic media such as email, call centers. Sometimes, it is also referred as E-service which means electronic services for customers without meeting in person. The concept of E-CRM is 'sense' and 'respond marketing' which means good relations with consumers will be realized if a company understands customer desires and uses them as opportunities as well as responds positively to consumer desires.

E-CRM is currently needed in order to save costs and improve the efficiency of managing customer relationships. It is believed that it has been used since the mid-1990s. At that time, the customers have started it by using web browsers, the internet and electronic transaction media, such as e-mail. ECRM is a CRM that is enhanced by using internet media.

\subsection{Database}

A database is a collection of data stored in a computer. The data can be processed, modified or manipulated with the help of software that aims to produce information. The definition of the database includes specifications, such as data types and data structures. In addition, there are also restrictions on the data to be stored. The database is an important aspect in information systems because it functions as a data storage repository. Furthermore, it is important because it has a role in organizing data, avoiding duplication, preventing the existence of unclear relationships between data. In processing the data to and from data storage media, it requires the help of software called DBMS or Database Management System. It is a software that makes database users easier to process, control and access the data practically and efficiently.

\section{RESEARCH METHODS}

Beauty Salon and Barber Shop Information Systems use waterfall-based lifecycle development software in designing systems. The SDLC model with the waterfall method has 5 stages in developing software, including analysis, design, implementation, testing and maintenance. These stages can be illustrated through Figure 1.

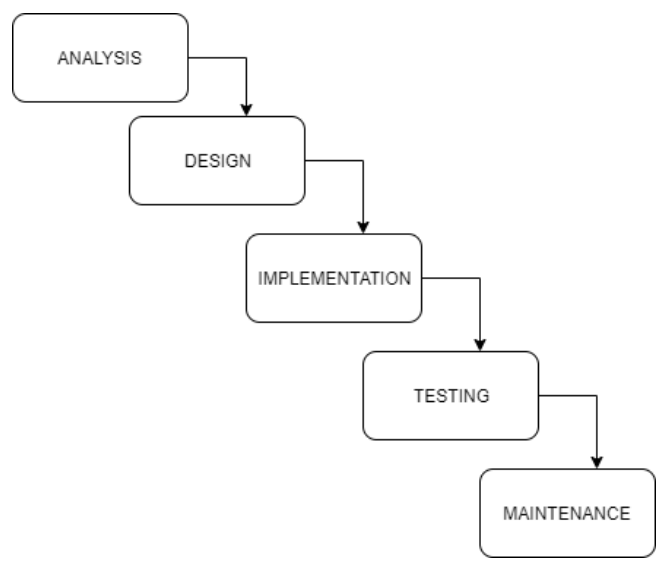

Figure 1. Stages of SDLC Waterfall

Figure 1 is the stage of system development by using the SDLC (System Development Life Cycle) waterfall method. It consists of 5 stages. Analysis is the first stage that is performed to be able to determine the needs in building and designing systems. This stage will answer all the needs of both the vendor and the customer. The second stage is designing the user interface of the beauty salon and barber shop information system. The third stage is implementing the information systems according to the needs of customers and vendors. The implementation requires several hardware devices such as smartphones and computers, while the software requires Android OS, Visual Studio Code, Android Studio, XAMPP and Windows 10. The fourth step is testing the system to find out the performance of it. The test was conducted to minimize errors or bugs contained in the system. If that problem happened, it can be fixed or redesigned. The fifth stage is the process of maintaining the system performance both from the internal system and errors caused by use. 


\subsection{General Overview of the System}

The general overview of the Salon and Barber Shop Geographic Information System with the Android-based ECRM approach is as shown on figure 2.

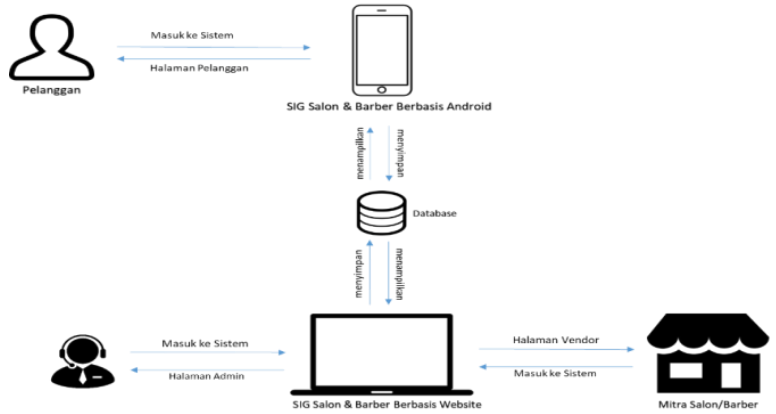

Figure 2. System's General Overview

Figure 2 is a general overview of the system where there are three actors whose interaction is facilitated by the system. Based on the figure, the customer can enter the system on an Android smartphone device to book a salon or barber service. The system stores information from the customers to the database. Furthermore, it informs the admin and the vendor based on the orders placed and in accordance with the transaction method chosen by the customer. Every customer's order will have a unique ID in order to identify the actor who has a role in confirming the order and storing detailed information of the order placed such as date and time, price, order list and others. The vendors use the system to manage vendor data, add vendor services, confirm top up balances and transactions through them. The admin is the actor who has the most extensive control of the system. They have the authority, such as accepting registration and confirmation of new vendors, managing vendor and customer data, managing transactions by using the payment transfer and balance method, managing top up with the transfer method, and managing promos

\subsection{Context Diagram}

Diagram context is a diagram that consists of a process that represents the whole system. It illustrates the input or output of a system. The context diagram of the beauty salon and barber shop information system is explained with Figure 3.

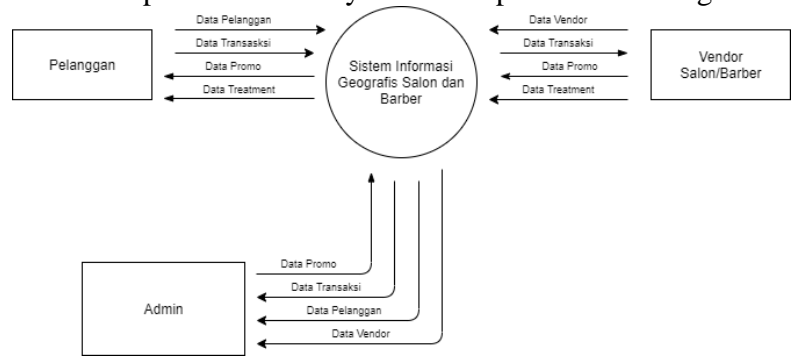

Figure 3. Context Diagram of Sabrina

Based on Figure 3, it can be seen that the beauty salon and barber shop information system process involves three external entities namely admin, customer, and vendor. The vendor is a service provider of the system. The system will provide and request information such as vendor data, promo data, transaction data, and treatment data provided by the beauty salon or barber shop. Customers can fill out personal data, make transactions, receive promo data and treatment contained in the vendor. Admin manages the process of Beauty Salon and Barber Shop Information system. In addition, it plays a role as a bridge of the transaction process between the beauty salon / barber shop vendor and the user.

\section{RESULT AND DISCUSSION}

The results and discussion on the application of the beauty salon and barber shop information systems will be explained in the form of booking feature, promotion and E-CRM feature testing.

\subsection{Booking Feature}

Customers can choose the treatment from each of barbershop and choose the desired time to get the service they ordered. The testing Booking feature can be seen in Figure 4.

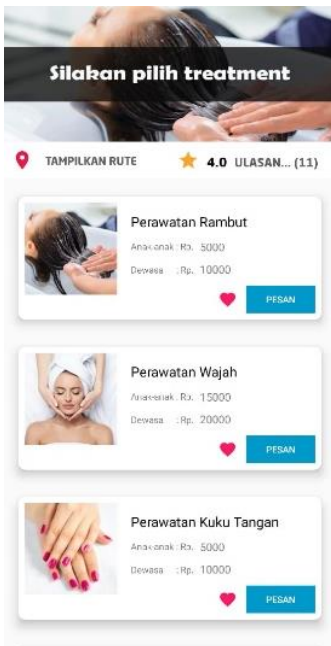

(a)

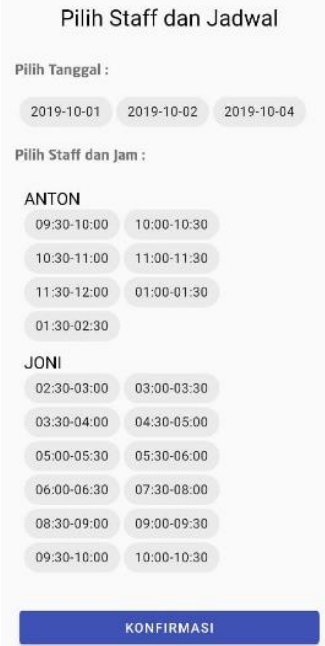

(b)
Figure 4. List of salons and treatment selection in booking process.

The customer can choose the treatment from each of registered beauty salon or barber shop in the system as shown in figure 4. (a). Then, the customer can determine the time when they want to get the treatment and employee information from the serving vendor as shown in figure 4. (b). The confirmation stage for incoming orders can be seen in Figure 5.

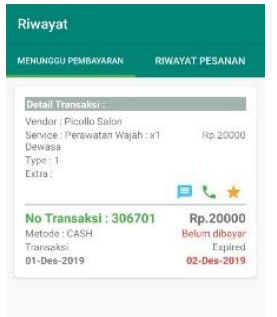

(a)

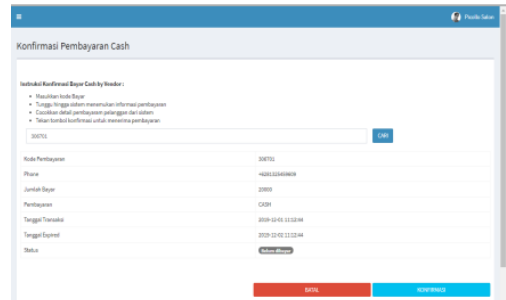

(b)
Figure 5. Customer's booking list and vendor's payment confirmation

Figure 5. (a) is a display of history when a customer has placed an order. The history shows a list of treatments that have not been paid yet and confirmed by the vendor. Figure 5 . (b) is a list of orders that will be confirmed by the vendor, therefore the customer can enjoy the treatment.

\subsection{Promotion Feature and E-CRM}


The promotion feature is part of implementing E-CRM on the system. Beside promotion feature, there are chat feature as well as ratings and reviews feature which are also part of the implementation of E-CRM. The testing of these features can be seen in Figure 6 and Figure 7 below.

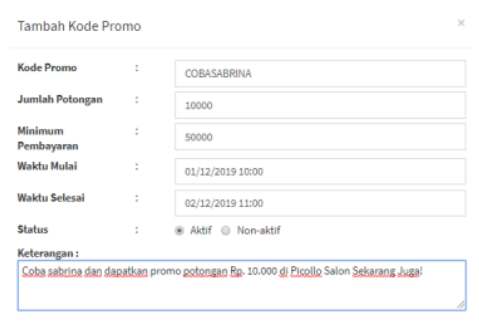

(a)

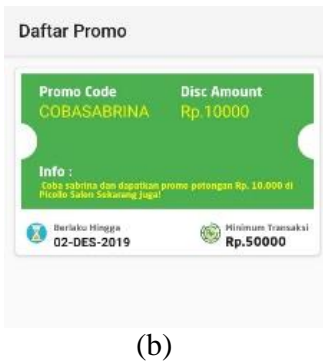

(b)
Figure 6. Vendor create a promo and customer checking the promo

Figure (a) is a feature provided for vendors in creating promotional codes. The promotional codes can be used by customers on the promo page as shown in figure (b).

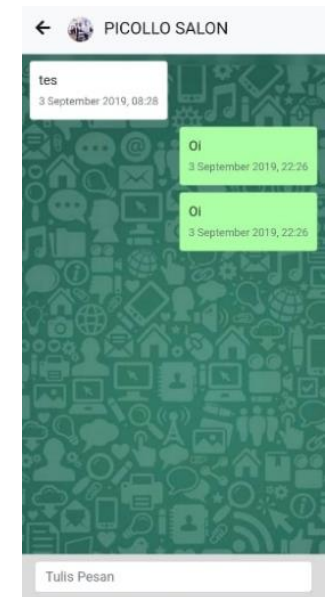

(a)

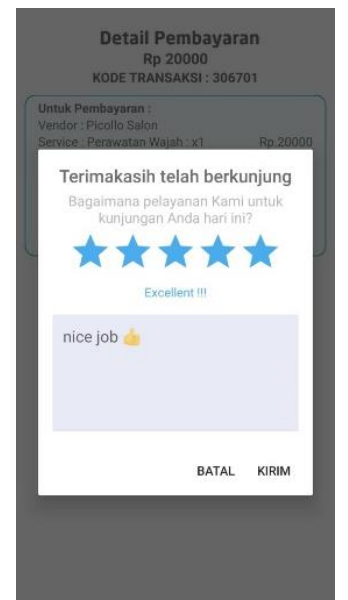

(b)
Figure 7. Chatting feature and Giving a review and rating

Figure 7. (a) is a chatting page provided as a communication tool between customers and vendors. Figure 7. (b) is ratings and reviews from the customers of services provided by vendors.

\section{CONCLUSION}

The Android Based High School Management Information The conclusions that can be drawn from implementing the system are as follows:

First, the design of beauty salon and barber shop information systems is conducted by making a general picture design, data flow diagrams, ERD and PDM as the basic structure in developing a database system. Second, the stages of the implementation of the information systems are using the Java programming language assisted by the Android Studio IDE. They were used in order to develop customer-side applications on the Android platform and PHP programming language to develop a web platform for the admin and vendor in dealing with customers. The testing process is conducted by testing both the Android platform application and the website platform application directly. Third, the results of the questionnaire show the measurement of E-CRM performance towards the Android-Based Beauty Salon and Barber Shop Geographic Information System which can be stated to be running well from the vendor and customer side.

\section{REFERENCES}

[1] I. W. G. N. I Putu Warma Putra, "Rancang Bangun Sistem Informasi Geografis Pemesanan Taksi Berbasis Android," J. Sist. dan Inform., pp. 50-59, 2014.

[2] B. Yuwono, A. S. Aribowo, and F. A. Setyawan, "Sistem Informasi Geografis Berbasis Android Untuk Pariwisata Di Daerah Magelang," J. Ilm. Tek. Inf., vol. 2015, no. 2015, pp. 68-74, 2015.

[3] Y. Yunefri, M. Devega, and D. Kristanto, "Geographic Information System ( Gis ) for Culinary in Pekanbaru using Herversine Formula Geographic Information System ( Gis ) for Culinary in Pekanbaru using Herversine Formula," 2017.

V. Neene and M. Kabemba, "Development of a Mobile GIS Property Mapping Application using Mobile Cloud Computing," IJACSA) Int. J. Adv. Comput. Sci. Appl., vol. 8, no. 10, pp. 57-66, 2017.

[5] Kusnawi, "Perancangan Sistem Informasi Pemesanan Meja Dan Makanan (Studi Kasus Restoran Abc)," J. Dasi, vol. 14, no. 1, pp. 40-43, 2013.

[6] R. Aulia, A. Zakir, H. Dafitri, D. Siregar, and H. Hasdiana, "Mechanism of Food Ordering in A Restaurant Using Android Technology," J. Phys. Conf. Ser., vol. 930, no. 1, 2017.

[7] D. Rosadi and F. O. Andriawan, "Aplikasi sistem informasi pencarian tempat kos di kota bandung berbasis android," J. Comput. Bisnis, vol. 10, no. 1, pp. 50-58, 2016.

[8] M. Afrina et al., "Rancang Bangun Electronic Costumer Relationship Management (E-CRM) Sebagai Sistem Informasi Dalam Peningkatan Layanan Perpustakaan Digital Fakultas Ilmu Komputer Unsri.," J. Sist. Inf., vol. 5, no. 2, pp. 629644, 2013.

[9] T. Le Tan, "Successful Factors of Implementation Electronic Customer Relationship Management (eCRM) on E-commerce Company," Am. J. Softw. Eng. Appl., vol. 6, no. 5, p. 121, 2017.

[10] T. Luarasi, A. Domi, T. Thomo, A. Kasaj, and E. Baboci, "Cloud based communication in B2B model," Proc. - Asia Model. Symp. 2014 8th Asia Int. Conf. Math. Model. Comput. Simulation, AMS 2014, pp. 27-32, 2014.

[11] N. Rosmawarni, "Perancangan sistem rekomendasi untuk pengembangan aplikasi salon terpadu berbasis android," Rekayasa Inf., vol. 6, no. 1, pp. 61-70, 2017.

[12] Tukino, "Rancang Bangun Sistem Informasi Customer Relationship Management (Crm) Berbasis Web," Comput. Based Inf. Syst. J., vol. 06, no. 01, pp. 12-22, 2018.

[13] I. Prastya, S. Hidayatuloh, and N. Hasanati, "RANCANG BANGUN i-CRM (INTERACTIVE CUSTOMER RELATIONSHIP MANAGEMENT) UNTUK JASA AGEN PERJALANAN WISATA (Studi Kasus: PT Persada Duta Beliton)," Stud. Inform. J. Sist. Inf., vol. 10, no. 1, pp. 45-52, 2018.

[14] Fandhilah, Dany Pratmanto, A. Fatakhudin, "Rancang Bangun Sistem Informasi E-Booking Ruang Karaoke Berbasis Web ( Studi Kasus: Karaoke Keluarga Happy Puppy )," Indones. J. Softw. Eng., vol. 3, no. 2, pp. 68-76, 2018. 
International Journal of Computer Applications Technology and Research

Volume 9-Issue 02, 53-58, 2020, ISSN:-2319-8656

[15] Devi Mawarni; Rinabi Tanamal, "Rancang Bangun Sistem Informasi pada Salon Skala Menengah," Inform. dan Sist. Inf. ISSN 2460- 1306, vol. 02, no. 01, pp. 74-81, 2016.

[16] L. G. Sri Handayani, I. N. Piarsa, and K. Suar Wibawa, "Sistem Informasi Geografis Pemetaan Jalan Desa Berbasis Web," CSRID (Computer Sci. Res. Its Dev. Journal), vol. 6, no. 3, p. 171, 2015.

[17] I. Widnyana, I. Piarsa, and A. Agung Cahyawan W., "Aplikasi Sistem Informasi Geografis Bengkel di Kota Denpasar Berbasis Android," Merpati, vol. 3, no. 1, pp. 23-30, 2016.

[18] I. W. W. Gautama, I. K. G. D. Putra, and I. M. Sukarsa, "Aplikasi Pemetaan Objek Wisata Pantai Bali Selatan Berbasis Android," Merpati, vol. 4, no. 1, pp. 43-51, 2016. 